\title{
FOREST DIVERSITY AND VITALITY OF THE IMPORTANT RELICT AND ENDANGERED FERN SPEGIES, BRAINEA INSIGNIS IN CHINA: IMPLICATIONS FOR CONSERVATION
}

\author{
Sun $\mathrm{L}^{1,2}$, Zhang $\mathbf{Y}^{3}$, Lee $\mathrm{SY}^{2}$, Cui $\mathbf{Y}^{2}$, Liang $\mathbf{P}^{3} \&$ Liao $\mathrm{W}^{2, *}$ \\ ${ }^{1}$ Guangdong Polytechnic of Science and Trade, Guangzhou, 510430, Guangdong, China \\ ${ }^{2}$ State Key Laboratory of Biocontrol and Guangdong Provincial Key Laboratory of Plant Resources, School of Life Sciences, \\ Sun Yat-sen University, Guangzhou, 510275, Guangdong, China \\ ${ }^{3}$ Shenzhen Wildlife Conservation Division, Shenzhen, 518048, Guangdong, China \\ *lsslwb@mail.sysu.edu.cn
}

Submitted September 2020; accepted November 2020

\begin{abstract}
Brainea insignis is the only species in the genus Brainea. It is widely distributed in the Asia and Australia continents, but usually in small, fragmented populations. Owing to its sensitivity towards habitat changes and human disturbance, the population of this fern is deteriorating. At present, it is classified as an endangered species in China. In this study, we assessed the forest diversity and vitality status of B. insignis in its natural habitat. A total of 63 vascular plant species belonging to 55 genera of 40 families were recorded in the $1200-\mathrm{m}^{2}$ study plot. The Raunkiaer's frequency index indicated that B. insignis was experiencing a decline in stand size and structure although the overall level of vitality was 18.58. One-way ANOVA revealed that significant differences were detected between the basal diameter, tree height, crown size, and number of leaves of B. insignis in the study plot, but not between tree height and number of leaves. Proper conservation management is requisite to ensure continuous survival of this relict species in the wild despite eqinterference from evolution and urbanisation from mankind.
\end{abstract}

Keywords: Diversity index, dominant species, medicinal herb, Mount Tiantou, monotypic genus

\section{INTRODUCTION}

Brainea insignis, also known as the cycad fern, is a tropical woodwardioid fern species belonging to the family of Blechnaceae. Although fossil discovery on woodwardioid ferns are scarce (Cranfill \& Kato 2003), members of the genus Brainea are speculated to be present during the Devonian of Paleozoic and flourished during the Jurassic of Mesozoic (Wang et al. 2003). However, according to the Pteridophyte Phylogeny Group (PPG I 2016), the genus has been reduced to only one species, and the sole surviving species, B. insignis, was reported to thrive in the Tertiary period (Gasper et al. 2016). Today, B. insignis can be found growing on damp and exposed hillsides with high light availability and low soil water content, at altitudes ranging from 300 to $1700 \mathrm{~m}$ (Wang et al. 2013), in the southern region of China as well as widely distributed in the Asia and Australia continents. The species highly resembles Cycas species of the Cycadaceae in general appearance and habitat, and can be distinguished by major characteristics of its reproductive parts (Liu et al. 2017). Needless to say, studies on B. insignis are scarce but emerging over time. Recently, development of expressed sequence tag-simple sequence repeat (EST-SSR) markers has aided genetic structuring diversity of natural B. insignis populations (Liu et al. 2017) and the characterisation of the complete B. insignis chloroplast genome has provided insights to the phylogenetic relationship of this relict species at the genome-scale level (Yu et al. 2020). Beyond that, information such as its population structure and regeneration of this species is scarce. Being a species that was listed as a protected species of Category II in China (Order of the Forestry Bureau and Ministry of Agriculture of China 1991) as well as a nearthreatened species in India (Fraser-Jenkins 2012), indicates that this species requires much attention in terms of its survival and conservation status in the wild.

In order to develop effective conservation strategies, basic information such as the forest 
community and species diversity could provide insights to evaluating the local threatened status of a fern species in its habitat (Balkrishna et al. 2020). Stability in the ecosystem is considered a key factor to a healthy forest stand, whereas for an endangered species, the regeneration behaviour of the species in a forest can be indicated by the presence of sufficient number of individuals from different age structure in a given population (Balkrishna et al. 2020). Considering that the stand structure of populations provides an indication of their regeneration process, we assessed the forest community characteristics and population structure of natural $B$. insignis in Mount Tiantou Nature Reserve (MTNR). MTNR is home to 1289 vascular plant species belonging to 699 genera and 191 families (Zhao et al. 2016). The nature reserve is also home to 44 protected species listed in the International Union for Conservation of Nature (IUCN) Red list and when compared with the forest area adjacent to MTNR, the preservation of biodiversity in MTNR is relatively better due to strict forest monitoring by local enforcement agencies. In this study, we aimed to obtain the vitality level of $B$. insignis in our study area and compared our data with a preliminary report conducted on the $B$. insignis forest community in MTNR in 2010 (Xu et al. 2010), as well as other similar assessments conducted previously in other forest stands in China. To provide a basic understanding of $B$. insignis, we reviewed local knowledge and conservation status of $B$. insignis in China. Recommendations for conservation management of B. insignis were also discussed.

\section{MATERIALS AND METHODS}

The study site is located in Jinguicun $\left(22^{\circ} 38^{\prime}-22^{\circ}\right.$ $43^{\prime} \mathrm{N}, 114^{\circ} 22^{\prime}-114^{\circ} 28^{\prime} \mathrm{E}$ ), a low-populated village located at the eastern border of the MTNR in the Pingshan County, Shenzhen. The $20-\mathrm{km}^{2}$ nature reserve consists of several hilly peaks with a maximum elevation of $683 \mathrm{~m}$, while the elevation range of the $B$. insignis populations extends $200-300 \mathrm{~m}$ above sea level. The area is covered with acidic red and yellow soil content as well as volcanic and granite rocks, while on the surface, it is dominated by secondary evergreen broad-leaved forests. The study area is characterised as subtropical to tropical humid climate which recorded an annual average temperature of $22.4^{\circ} \mathrm{C}$, and could reach the highest recorded temperature of $36.6{ }^{\circ} \mathrm{C}$ during warmer months and the lowest recorded temperature of $1.4{ }^{\circ} \mathrm{C}$ during the cold months. The annual relative humidity is $80 \%$ and the annual precipitation is $1933 \mathrm{~mm}$ over 140 days. Jinguicun has a hiking trail access into MTNR. As a natural habitat to $B$. insignis that is affected by human disturbance, the study site is suitable in providing an understanding to the survival of $B$. insignis in the wild.

To assess $B$. insignis at the study site, we established a plot of $1600 \mathrm{~m}^{2}$ in MTNR. The plot was divided into 16 smaller quadrats $(10 \mathrm{~m} \times 10 \mathrm{~m})$, randomly selected and were widely separated from each other at least $100 \mathrm{~m}$ apart. Species names, diameter breast height (DBH), height, and crown width were recorded for all vascular plants with $\mathrm{DBH} \geq 1.5 \mathrm{~cm}$ and height $\geq 1.5 \mathrm{~m}$. The number of individuals and the area coverage of undergrowth shrubs, herbs, and interlaminar lianas in a $2 \mathrm{~m} \times 2 \mathrm{~m}$ quadrat within each $10 \mathrm{~m} \times$ $10 \mathrm{~m}$ quadrat were also recorded.

Individuals with $\mathrm{DBH}$ of $\geq 2.5 \mathrm{~cm}$ were considered adults, while those that had DBH of $<2.5 \mathrm{~cm}$ and height of $\geq 33 \mathrm{~cm}$ were considered saplings. However, saplings that were $<33 \mathrm{~cm}$ were regarded as seedlings. Five different frequency ranks, namely, A, B, C, D and E were specified based on the range of percentage of $0-19.9$, 20-39.9, 40-59.9, 60-79.9 and 80-100 respectively (Wang et al. 1996). The importance value index (IVI) (Curtis \& McIntosh 1951) for each species in the plot was calculated and the dominant species were selected according to their value of importance. The formula is as follows:

$$
\begin{aligned}
\mathrm{IVI}= & (\text { Relative frequency }+ \text { relative abundance } \\
& + \text { relative prominence }) / 3
\end{aligned}
$$

The relative prominence for tree species was based on the basal area at breast height, while for shrubs and herbs, on their percentage of coverage. Based on the Raunkiaer's frequency index, the stand classification of the dominant species was analysed for tree and shrub layers across five tree classes, i.e. class I = seedlings, class $\mathrm{II}=$ saplings, class III $=$ trees that had $\mathrm{DBH}<7.5 \mathrm{~cm}$, class IV $=$ trees that had $\mathrm{DBH}$ ranging from $\geq 7.5 \mathrm{~cm}$, but were $<22.5 \mathrm{~cm}$, and class $\mathrm{V}=$ trees that had DBH $\geq 22.5 \mathrm{~cm}$ (Wang et al. 1996).

In order to compare the results of this study with those obtained by Xu et al. (2010), species diversity within the study plots was calculated 
using Shannon-Wiener diversity index $\left(\mathrm{H}^{\prime}\right)$ (Shannon \& Weaver 1969), Simpson's index of dominance $\left(\mathrm{C}_{\mathrm{D}}\right)$ (Simpson 1949), and evenness index (e) (Pielou 1966). The formula for each index is as follows:

Shannon-Wiener diversity index:

$$
\mathrm{H}^{\prime}=\sum_{\mathrm{i}=1}^{\mathrm{S}} \mathrm{P}_{\mathrm{i}} \ln \mathrm{P}_{\mathrm{i}}
$$

Simpson's index:

$$
\mathrm{C}_{\mathrm{D}}=\sum_{\mathrm{i}=1}^{\mathrm{S}}\left(\mathrm{P}_{\mathrm{i}}\right)^{2}
$$

Evenness index:

$$
\mathrm{e}=\mathrm{H}^{\prime} / \log \mathrm{S}
$$

where, $\mathrm{P}_{\mathrm{i}}$ represents the proportional abundance of the $\mathrm{i}^{\text {th }}$ species in the community and $\mathrm{S}$ is the total number of species.

In each study plot, we counted the number of $B$. insignis individuals and recorded the basal diameter of stem at $1.3 \mathrm{~m}$ above ground surface, tree height, crown size, and the number of normal healthy leaves. The level of vitality $(\mathrm{V})$ of B. insignis in the study plot was calculated based on the formula given below:

$$
V=0.2 a+0.2 b+0.2 c+0.2 d+0.1 e+0.1 f
$$

where, a is the average leaf number for B. insignis, $\mathrm{b}$ is the average crown size, $\mathrm{c}$ is the number of individuals, $\mathrm{d}$ is the average basal diameter, $\mathrm{e}$ is the average tree height, and $\mathrm{f}$ is the number of quadrats recorded in the study plot. The level of vitality from this study was compared with those of other populations in Guangdong province (Cai et al. 2014, Liu et al. 2016, Zeng et al. 2016) . One-way ANOVA was performed to determine whether or not significant differences were present between the measurements on the four morphological features (basal diameter, height, crown size and number of leaves). The measurements were assigned into several classes for calculation purposes, whereby basal diameter was assigned into five classes $(\leq 0.50,0.51-10.00$, $10.01-15.00,15.01-20.00,>20.00 \mathrm{~cm})$, tree height five classes $(\leq 0.5,0.6-1.0,1.1-1.5,1.6-2.0$, $>2.0 \mathrm{~m})$, crown size four classes $(\leq 2.0,2.1-4.0$, $\left.4.1-6.0,>6.0 \mathrm{~m}^{2}\right)$, and the number of leaves five classes $(\leq 6,7-12,13-18,19-24,>24)$. Significant difference ( $p$-value) was set at $\leq 0.05$.

\section{RESULTS}

\section{Floristic composition of MTNR}

A total of 63 species of vascular plant species, belonging to 55 genera and 40 families were recorded in the study area. Rubiaceae had six species and was classified as the dominant family in the study area, followed by Euphorbiaceae, Lauraceae, and Rutaceae which had three species each (Appendix). The study area represented an evergreen community appearance and unobvious seasonal change, belonging to a typical evergreen broad-leaved forest in the subtropical monsoon zone. The forest can be categorised into three different layers on the basis of vertical structure layers, namely, tree, shrub and herb. The tree layer was further divided into another two sublayers which were upper and bottom. The upper sublayer (10-18 m in height) comprised tree species such as Aporusa dioica, Diospyros morrisiana, Elaeocarpus sylvestris, Lithocarpus glaber, Machilus pauhoi, Sapium discolor, Schefflera heptaphylla and Syzygium hancei. The bottom sublayer (6-10 $\mathrm{m}$ in height) had 29 other tree species such as Cratoxylum cochinchinense, Gordonia axillaris and Itea chinensis. The shrub layer (1-5 $\mathrm{m}$ in height) consisted of more than 30 plant species, including B. insignis, Diplospora dubia, Glochidion wrightii, Ilex pubescens, Litsea rotundifolia and Psychotria rubra. The herb layer was predominantly monocotyledons and ferns such as Adiantum flabellulatum, Blechnum orientale, Dicranopteris dichotoma, Lindsaea orbiculata and Lophatherum gracile. On the other hand, four interlayer plant species, namely, Dendrotrophe frutescens, Lygodium flexuosum, Lygodium japonicum, and Tetracera asiatica were also recorded.

\section{Species dominance and diversity}

In this study, the number (and percentage) of plant species that were grouped into ranks A, B, C, D, and E were 38 (57.58\%), 15 (22.73\%), 8 (12.12\%), $2(3.03 \%)$; and $3(4.55 \%)$ respectively. The frequency distribution index was $\mathrm{A}>$ $\mathrm{B}>\mathrm{C}>\mathrm{D}<\mathrm{E}$. The first three species which had the highest IVI were treated as dominant species in each layer. In the tree layer, L. glaber $(\mathrm{IVI}=61.17 \%), S$. heptaphylla $(9.26 \%)$, and 
S. hancei $(5.00 \%)$ were the dominant species (Table 1). For shrub layer, P. rubra (37.52\%), B. insignis $(13.69 \%)$ and L. rotundifolia var. oblongifolia $(5.20 \%)$ were dominant species. The dominant herb species were L. orbiculata $(6.95 \%)$, D. pedata $(3.49 \%)$ and L. gracile $(2.94 \%)$.

Lithocarpus glaber and S. heptaphylla had the highest percentage of standing trees in class IV (43.11 and $67.86 \%$ respectively) and lowest in class I (0.25 and $0.00 \%)$ (Figure 1$)$. However, $S$. hancei had most standing trees in classes II and III $(43.48 \%$ each), but did not have any stands recorded for class V. Psychotria asiatica was the highest number of standing trees in class II $(62.12 \%)$, while B. insignis and L. rotundifolia var. oblongifolia were abundant in classes IV $(76.32 \%)$ and III (77.78\%) respectively. No stands were recorded for $P$. asiatica in classes I and V, B. insignis in class $\mathrm{V}$, and $L$. rotundifolia var. oblongifolia in classes I, IV and V. The overall species diversity in MTNR, based on the Shannon-Wiener, Simpson and evenness indices, were $3.18,5.12$, and 0.73 respectively (Table 2 ).

\section{Population structure of $B$. insignis}

There was a total of $74 \mathrm{~B}$. insignis individuals recorded in the study plot. Of these, 44 of them had a basal diameter of stem at $1.3 \mathrm{~m}$ above groud surface. The average basal diameter for the recorded individuals was $8.53 \mathrm{~cm}$, with an average height of $41.70 \mathrm{~cm}$. The average crown size was $1.54 \mathrm{~m} \times 1.45 \mathrm{~m}$, which had an average of 16.84 leaves per individual. The natural population of $B$. insignis in MTNR had an overall vitality level of 18.58 (Table 2). Oneway ANOVA revealed that there were significant differences between the basal diameter and the tree height, crown size and number of leaves as well as between crown size and tree height and number leaves (Table 3). However, there was no significant difference between tree height and number of leaves.

\section{DISCUSSION}

\section{Community characteristics of MTNR}

MTNR has an evergreen forest stand and unnoticeable seasonal change that fits the criteria of a typical evergreen broad-leaved forest in the subtropical monsoon zone. The frequency distribution of the five ranks in MTNR is consistent with Raunkiaer's law of distribution of frequencies (Raunkiaer 1934), in which the presence of high proportion of rank E species representing the constructive and dominant species in the forest stand indicated a stable state of the present forest stand structure in MTNR. On the contrary, presence of higher proportions in rank $B$ and rank $C$ species would be an indication of an uneven species distribution in the forest stand. The Raunkiaer's standard frequency index suggested that ranks A, B, C, D, and $\mathrm{E}$ should have a standard frequency of 53, $14,9,8$ and $16 \%$ respectively (Raunkiaer 1934). In MTNR, higher frequencies were recorded for ranks $\mathrm{A}, \mathrm{B}$ and $\mathrm{C}$ but lower for ranks $\mathrm{D}$ and $\mathrm{E}$. This suggested that the forest stand in MTNR was at the stage of a subclimax community, and the process to achieve the final stage of succession was ongoing.

Based on the value for importance of dominant species recorded in this study, MTNR could be regarded as a L. glaberP. rubra community. The stand classification on dominant species within a community not only reflects its role and position, but also the stand succession as well as development trends (Kangur et al. 2005). The high proportion in class IV but low proportion in class $\mathrm{V}$ for L. glaber and S. heptaphylla indicated that the two species were going through a pre-development stage and the most dominant species, L. glaber, was experiencing a second round of secondary succession stage. Judging by the current stand classification of $L$. glaber, the species was likely to propagate growth pattern in terms of its stand size and structure. On the contrary, based on the stand classification of S. heptaphylla, the high proportion of stands in class IV but low proportions of stands in classes II and III indicated that although the species was growing vigorously in the study area, it was experiencing a declining trend in stand size and structure. On the other hand, stand size and structure of $S$. hancei will likely increase in future as it had larger proportions of stands in classes II and III. In the shrub layer, although P. rubra stands showed substantial growth in stand size, in which stand proportion in class II was greater than III and stand proportion in class III was greater than IV, the species was unlikely to achieve absolute dominancy in future succession. This was because the species was restricted to its vegetative characteristics, in which the mature 


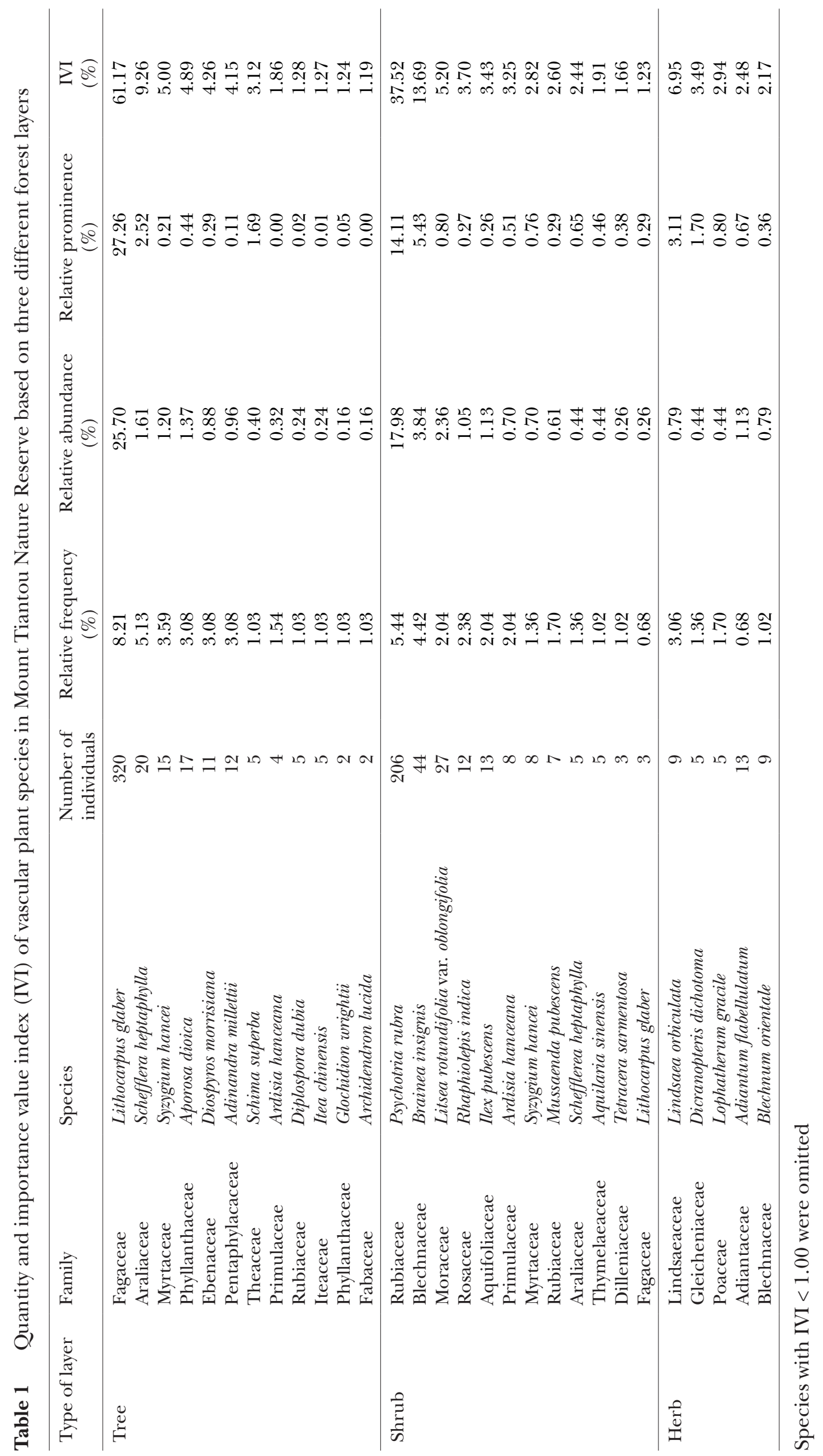




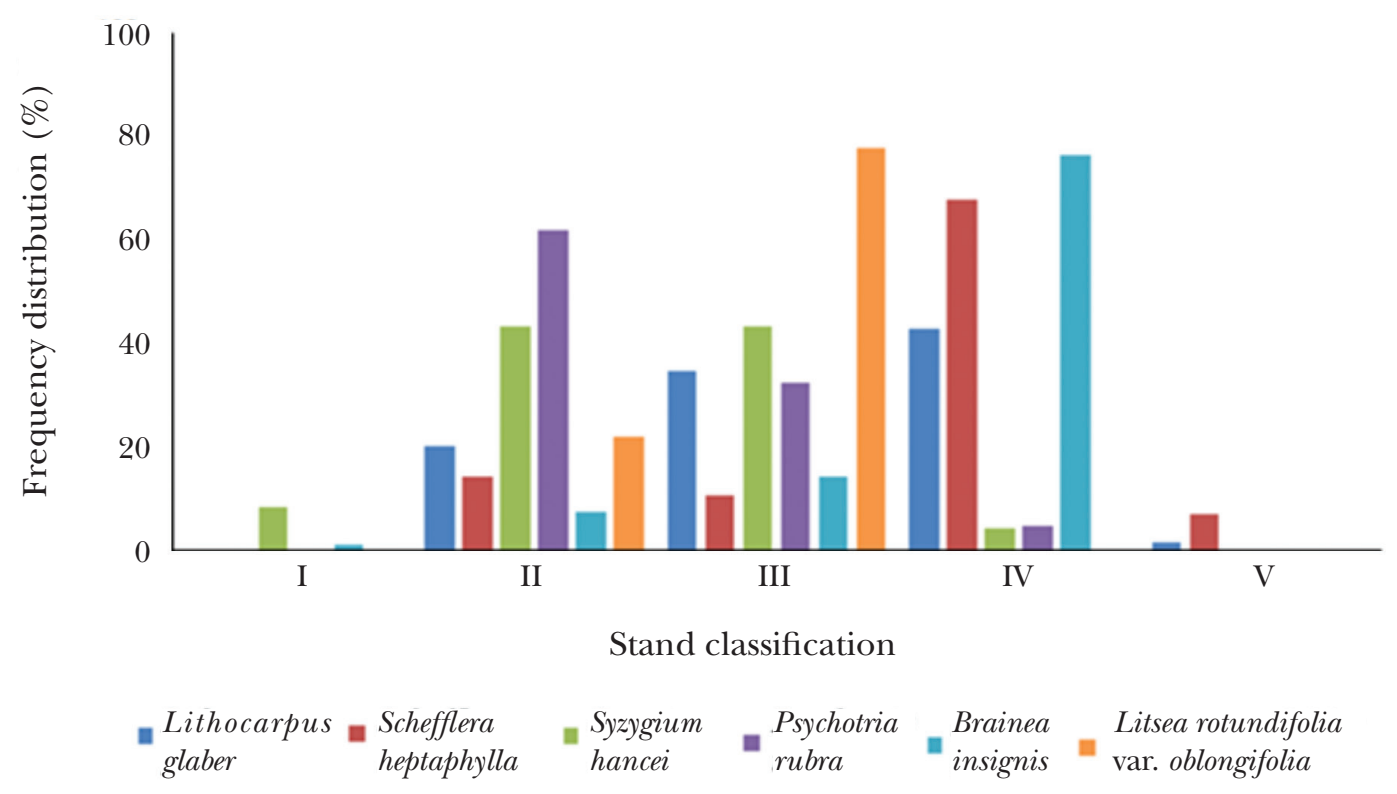

Figure 1 Stand classification and frequency distribution of six dominant species (three species each for tree and shrub layer) identified based on their importance value in Table 1; stand classification of the dominant species was based on five tree classes, i.e class I = seedlings, class II = saplings, class $\mathrm{III}=$ trees that had $\mathrm{DBH}<7.5 \mathrm{~cm}$, class IV = trees that had $\mathrm{DBH}$ ranging from $\geq 7.5 \mathrm{~cm}$, but were $<22.5 \mathrm{~cm}$, class $\mathrm{V}=$ trees that had $\mathrm{DBH} \geq 22.5 \mathrm{~cm}$

form could only reach a maximum height of $1.5 \mathrm{~m}$ due to its heavy branching features. By having a similar stand structure as $S$. heptaphylla, B. insignis stands in MTNR was also experiencing a declining trend in stand size and structure. As for $L$. rotundifolia var. oblongifolia, the species showed promising growth pattern for the future. Another endangered tree species, Aquilaria sinensis, was only represented by a handful number at the shrub layer. Considering that the A. sinensis tree could reach a maximum height of $15 \mathrm{~m}$ during maturity stage (Wang et al. 2007), the limited number of seedlings recorded in the study plot suggested that the survival of A. sinensis in this area could be challenging. Aquilaria sinensis populations are threatened by human activities, such as illegal harvesting or discriminate felling in search of agarwood (Jim 2015), thus it is listed in the IUCN Red List as vulnerable (Harvey-Brown 2018) and included in Appendix II of the Convention on the International Trade of Endangered Species of Wild Fauna and Flora (CITES) (UNEP-WCMC 2020). Although it may consume a long period of time, forest recovery after human disturbance is likely to be challenging but possible ( $\mathrm{Sann}$ et al. 2016).

\section{Population status of $\boldsymbol{B}$. insignis}

The population of $B$. insignis in MTNR was suffering a weak self-renewal ability which may be caused by the vegetative characteristics of its habitat such as dense canopy, insufficient growing space and other external environmental factors. Xu et al. (2010) reported that B. insignis population in MTNR in 2010 had slightly higher species diversity, indicating that MTNR had encountered a decrease in species diversity over the last decade (Table 2). The decreasing growth trend in B. insignis stand size and structure was not only observed in this study, but the same trend was also being reported elsewhere (Cai et al. 2014, Liu et al. 2016).

Natural B. insignis populations in habitat which receives less sunlight than usual, have low vitality level. For example, B. insignis stands in Jingxin Reservoir that were recorded with low vitality levels, were generally distributed in gully areas which were high in moisture content and well-shaded. Dominant species in the upper layer of the study area had high canopy density, blocking the light from reaching the forest floor. This was one of the affecting factors that contributed to the low regeneration rate of 


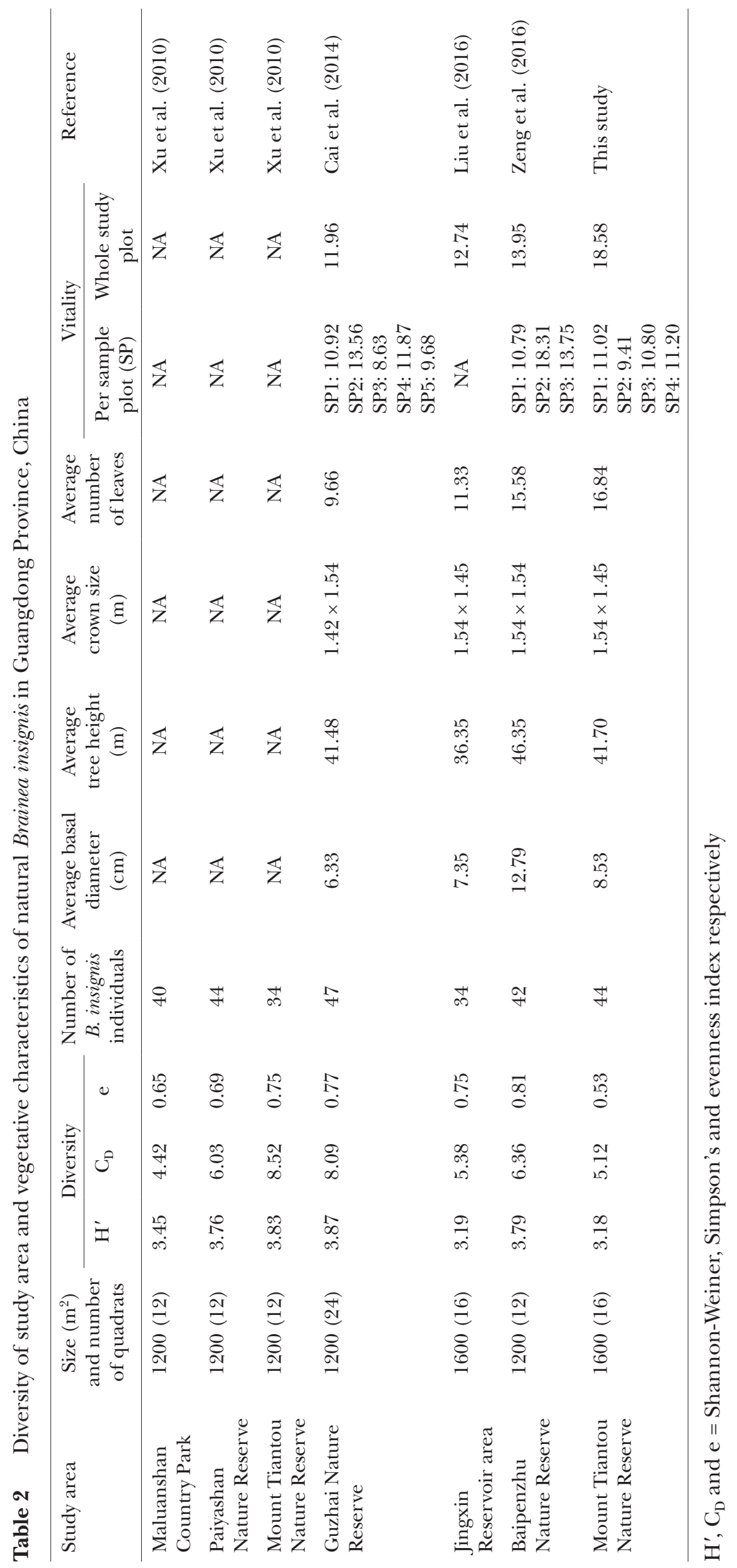


B. insignis in the area. However, when compared with three natural populations in Guangdong Province, i.e. Baipenzhu Nature Reserve, Guzhai Nature Reserve, and Jingxin Reservoir area, the overall vitality level of $B$. insignis from MTNR was the highest (Table 2). We observed a similar situation for B. insignis stands in sample plot 1 (SP1) of our study site, where the forest canopy was slightly denser when compared with that of sample plots 2, 3 and 4 (SP2, SP3, and SP4). Although B. insignis are naturally distributed widely in the southern region of China, the fern is known to favour habitats along hillsides and undisturbed environment. Brainea insignis can only be spotted in nature reserves, where the habitat is less likely to be destroyed (Yang et al. 2011).

\section{Conservation implications of $B$. insignis}

Presently, B. insignis is listed under the Chinese National Key Protection plant species with a level II protection status. It was previously thought to be an endemic species in China but was later discovered scattered in small fragmented populations in neighbouring countries and throughout the South-East Asia region (Yang et al. 2011). The conservation efforts of natural B. insignis populations are similar to other fern species, which are mainly based on in-situ and ex-situ approaches. For insitu conservation, the natural habitat of the fern is prioritised. Researchers have deployed various techniques to effectively identify appropriate protected areas for endangered ferns (Wang et al. 2016). One of the methods applied on natural B. insignis populations was through spatial model distribution using digital elevation model, orthophoto base maps and nine-date SPOT images (Wang et al. 2012). Through this technique, potential sites for the fern in the study area was predicted based on the reported habitat characteristics of B. insignis. However, due to limitation of low-resolution images, the output using such technique was unlikely to accurately extrapolate the spatial patterns of $B$. insignis in a highly precise manner. Therefore, conducting timely on-ground field survey and biodiversity assessments are still considered the most preferable method of choice to collect firsthand information on the habitat and population status of the fern.

As a typical mesophyte species, B. insignis is light-demanding and grows well in the hillside forest with moderate canopy density. However, these landscapes are often prone to fire during dry seasons (Kholia et al. 2019). In order to secure the moisture content of the surrounding, it is important that proper canopy density and forest structure is maintained. Appropriate manual forest floor cleaning may create sufficient gap to construct natural soil spore banks that allow the fern to propagate and regenerate. The potential role of spore bank in the soil has been brought up during the early 90 s and was proven to be an effective method to recovering small populations, but was only practised in temperate regions (Dyer \& Lindsay 1996). In Asia, India was the first to propose exploiting the efficiency of soil spore banks towards conservation of Asian ferns. Soil spore bank research is necessary and should align with the development of rural areas where deforestation for urbanisation occurs.

Based on the information compiled through the Biological Resources Programme of the Chinese Academy of Science (www.casbrc. org), ex-situ collection of living B. insignis is available at six botanical gardens distributed in the southern region of China. Ex-situ measures are popular and effective for fern preservation, and they complement in-situ

Table 3 Results of one-way ANOVA on the mean differences between basal diameter, tree height, crown size and number of leaves of 44 Brainea insignis individuals Mount Tiantou Nature Reserve

\begin{tabular}{|c|c|c|c|c|c|c|}
\hline & \multicolumn{2}{|c|}{ Tree height } & \multicolumn{2}{|c|}{ Crown size } & \multicolumn{2}{|c|}{ Number of leaves } \\
\hline & $\mathrm{p}$ & $\mathrm{F}$ & $\mathrm{p}$ & $\mathrm{F}$ & $\mathrm{p}$ & $\mathrm{F}$ \\
\hline Basal diameter & $1.2 \mathrm{E} 6 *$ & 25.56 & $0.04 *$ & 4.11 & $2.65 \mathrm{E} 6 *$ & 23.90 \\
\hline Tree height & & & $5.88 \mathrm{E} 11^{*}$ & 50.01 & 0.65 & 0.21 \\
\hline Crown size & & & & & $4.61 \mathrm{E} 10 *$ & 44.66 \\
\hline
\end{tabular}

*significant difference $(p)$ at $\leq 0.05$ 
conservation programmes (Ibars \& Estrelles 2012). Ex-situ fern collections in botanical gardens are important resources for fern spore banks, in which spores from endangered fern species, such as B. insignis, can be germinated and cultivated for replanting purposes. The concept of Fernarium, which is an ex-situ collection dedicated to only endangered ferns, was first introduced in 2012 (Bidin 2012). The major advantage of the Fernarium is to serve as an outdoor laboratory for morphological, cytological and phytochemical investigation and, at the same time, to aid in systematic classification of the pteridophytes. Botanical gardens and Fernariums are good platforms for promoting the biodiversity and delivering public awareness (Chen \& Sun 2018). Therefore, it is important to strengthen the capacity and scientific research in botanical gardens in order to become an effective tool for conservation and utilisation.

Efforts to promote $B$. insignis as ornamental plant are widely carried out but not properly regulated in China. Eventually, the demand for B. insignis as ornamental landscaping plant has influenced the increase of illegal harvesting of wild $B$. insignis saplings. To cater for the increasing demand for this endangered fern species, regulation to monitor and to promote sustainable utilisation with minimum disturbance to natural populations is essential. For this purpose, research into cultivation and domestication of $B$. insignis has led to the development of human-aided reproduction techniques. As a result, Chinese researchers have studied the germination rate of $B$. insignis spores and the success rate of clonal stands through stem plugs and the domestication of B. insignis seems to be promising (Lin 2008, Gao 2011). However, in order to reduce further exploitation of $B$. insignis in the wild, constant delivery of public awareness messages is necessary to educate the locals in preserving the nature (Ghosh et al. 2017).

\section{CONGLUSIONS}

Conservation of a relict species is always in line with the precise assessment and understanding of its survival dynamics. It is unsure that the $B$. insignis will be able to survive into the future without conservation and restoration efforts. Habitat alterations and reduction of species richness and diversity in the community where B. insignis is distributed have imposed a declining trend of its population status in the wild. The findings of this study may provide baseline information for formulating conservation and management strategies for natural B. insignis populations.

\section{ACKNOWLEDGEMENTS}

The authors thank the staff of Mount Tiantou Nature Reserve for the services rendered during fieldwork. This research was funded by the Shenzhen Assessment of Rare, Endangered and Important Wild Plant Resources Project (SZCG2014044440) and the Shenzhen Dapeng Peninsula National Geopark Science and Technology Innovation Project (HT-999820200258; 2020-2021).

\section{REFERENGES}

Balkrishna A, Arya V \& Kushwaha AK. 2020. Population structure, regeneration status and conservation measures of threatened Cyathea spp. Journal of Tropical Forest Science 32: 414-421. https://doi.org/10.26525/ jtfs2020.32.4.414

BIDIN A. 2012. The role of the Fernarium as a sanctuary for the conservation of threatened and rare ferns, with particular reference to Malaysia. Pp 223-240 in Heywood VH \& Jackson PW (eds) Tropical Botanic Gardens: Their Role in Conservation and Development. Academic Press, Cambridge.

Cai Z, Wu L, Cheng F, Ma L, Liu S \& CaO H. 2014. Study of Brainea insignis communities characteristics at Guzhai Nature Reserve, Huicheng District. Guangdong Forestry Science and Technology 30: 7-12.

Chen G \& Sun W. 2018. The role of botanical gardens in scientific research, conservation, and citizen science. Plant Diversity 40: 181-188. https://doi. org/10.1016/j.pld.2018.07.006

Cranfill R \& Kato M. 2003. Phylogenetics, biogeography, and classification of the woodwardioid ferns (Blechnaceae). Pp 25-48 in Chandra S \& Srivastava M (eds) Pteridology in the New Millennium. Springer, Dordrecht. https://doi.org.10.1007/978-94-0172811-9_4

Curtis JT \& McIntosh RP. 1951. An upland forest continuum in the prairie-forest border region of Wisconsin. Ecology 32: 476-496. https://doi.org/10.2307/1931725

DYER AF \& LiNDSAY S. 1996. Soil spore banks-a new resource for conservation. Pp 153-160 in Camus JM et al. (eds) Pteridology in Perspective. Royal Botanic Gardens, Kew.

Fraser-Jenkins CR. 2012. Rare and threatened Pteridophytes of Asia 2. Endangered species of India-the higher IUCN categories. Bulletin of the National Museum of Nature and Sciences, Series B, Botany 38: 153-181.

GaO P-S. 2011. Plug Production of Brainea insignis (Hook.) J.Sm. National Taiwan University, Taipei City. 
Gasper AL, Dittrich Vado, Smith AR \& Salino A. 2016. A classification for Blechnaceae (Polypodiales: Polypodiopsida): new genera, resurrected names, and combinations. Phytotaxa 275: 191-227. https:// doi.org/10.11646/phytotaxa.275.3.1

Ghosh S, Ganga M, Priyanka RR \& Manimaran P. 2017. Endangered ornamental plant species in India and strategy for their conservation-a review. Chemical Science Review and Letters 6: 1457-1464.

Harvey-Brown Y. 2018. Aquilaria sinensis. The IUCN Red List of Threatened Species. http://dx.doi.org/10.2305/IUCN. UK.2018-2.RLTS.T32382A2817115.en

Ibars AM \& Estrelles E. 2012. Recent developments in ex situ and in situ conservation of ferns. Fern Gazette 19: 67.

Jiм CY. 2015. Cross-border itinerant poaching of agarwood in Hong Kong's peri-urban forests. Urban Forestry E Urban Greening 14: 420-431. https://doi. org/10.1016/j.ufug.2015.04.007

Kangur A, Korjus H, Jögiste K \& Kiviste A. 2005. A conceptual model of forest stand development based on permanent sample-plot data in Estonia. Scandinavian Journal of Forest Research 20: 94-101. https://doi.org/10.1080/14004080510041039

Kholia BS, Sharma S \& Sinha BK. 2019. Brainea insignis (Hook.) J.Sm.- - conservation priority fern of North East India. Current Science 116: 32-35. https://doi. org/10.18520/cs/v116/i1/32-35

Lin X-X. 2008. Studies of Phenology, Spore Propagation, and Effects of Temperature and Nutrition Concentration on Growth of Brainea insignis (Hook.) J.Sm. National Taiwan University, Taiwan.

Liu H, Xu K, Sun H, He Q, Fan Q \& Liao W. 2016. Structure characteristics and succession analysis of Brainea insignis community in Jingxin Reservoir Area. Acta Botanica Boreali-Occidentalia Sinica 36: 2094-2102.

Liu H, Yan Z, Xu H, Li C, Fan Q, Liao W \& Liao B. 2017. Development and characterization of EST-SSR markers via transcriptome sequencing in Brainea insignis (Aspleniaceae s.1.). Applications in Plant Science 5: 1700067. https://doi.org/10.3732/apps.1700067

Order of the Forestry Bureau and Ministry of Agriculture of China. 1991. The Protected Native Plant List in China $\left(1^{\text {st }}\right.$ List). Ministry of Agriculture, Beijing.

PIELOU EC. 1966. Shannon's formula as a measure of specific diversity: its use misuse. The American Naturalist 100: 463-465. https://doi.org/10.1086/282439

PPG I. 2016. A community-derived classification for extant lycophytes and ferns. Journal of Systematics and Evolution 54: 563-603. https://doi.org/10.1111/ jse. 12229

Raunkiaer C. 1934. The Life Forms of Plants and Statistical Plant Geography. Clarendon Press, Oxford.

SAnN B, KanZaKi M, Aung M \& Htay KM. 2016. Assessment of the recovery of a secondary tropical dry forest after human disturbance in central Myanmar. Journal of Tropical Forest Science 28: 479-489.
Shannon CE \& Weaver W. 1969. The Mathematical Theory of Communities. University of Illinois Press, Urbana.

Simpson EM. 1949. Measurement of diversity. Nature 163: 688. https://doi.org/10.1038/163688a0

UNEP-WCMC. 2020. The checklist of CITES species website. http:/ / checklist.cites.org. (accessed on 1 June 2020)

WAng B, YU S \& Peng S. 1996. Experiment Handbook of Phytocoenology. Guangdong Higher Education Press, Guangzhou.

Wang C, Wan J, Zhang Z \& Zhang G. 2016. Identifying appropriate protected areas for endangered fern species under climate change. Springerplus 5: 904. https:/ / doi.org/10.1186/s40064-016-2588-4

Wang FG, XIng FW, Dong SY \& Kato M. 2013. Blechnaceae. Pp 411-417 in Wu ZY et al. (eds) Flora of China. Volumes 2-3. Science Press, Beijing and Missouri Botanical Garden Press, St. Louis.

WAng W-C, Lo N-J, Chang W-I \& Huang K-Y. 2012. Modeling spatial distribution of a rare and endangered plant species (Brainea insignis) in central Taiwan. International Archives of the Photogrammetry, Remote Sensing and Spatial Information Sciences 39: 241246. https://doi.org/10.5194/isprsarchivesxxxix-b7-241-2012

WANG Y, Nevling LI \& Gilbert MG. 2007. Aquilaria Lamarck. Pp 214-215 in Wu ZY et al. (eds) Flora of China. Volume 13. Science Press, Beijing and Missouri Botanical Garden Press, St. Louis.

Wang Y, Zhang S, Li Y, Cheng J \& Xing F. 2003. The floristic characteristics and distribution of National Key Protected Wild Plants in Shenzhen. Journal of South China Agricultural University 24: 63-66.

Xu X, Wang X, Sun Y, Lai Y, Zan Q \& Liao W. 2010. Analysis on community characteristics of Brainea insignis in Maluanshan and its adjacent mountains of Shenzhen. Journal of Plant Resources and Environment 19: 63-69.

Yang FC, Zhang CL, Wu G, Liang SY \& Zhang XC. 2011. Endangered pteridophytes and their distribution in Hainan Island, China. American Fern Journal 101: 105-116. https://doi.org/10.1640/0002-8444101.2.105

Yu J, Wang H, Dong H, Fang Y \& XIang J. 2020. The complete chloroplast genome sequence of Brainea insignis (Blechnaceae). Mitochondrial DNA Part B: Resources 5: 2034-2035. https://doi.org/10.1080/23802359. 2020.1756959

ZenG S, Ma D, Liao Yet al. 2016. Communities characteristics with the populations of Brainea insignis in Lianhuashan-Baipenzhu Nature Reserve, Guangdong. Journal of Fujian Forestry Science and Technology 43: 8-13.

Zhao Q, Liu L, Chen D \& Sun H. 2016. Investigation of plant resources in Shenzhen Tiantoushan Municipal Nature Reserve. Journal of Green Science and Technology 14: 4-7. 
Appendix Species and number of vascular plant individuals recorded in Brainea insignis community in Mount Tiantou Nature Reserve, Shenzhen, China

\begin{tabular}{|c|c|c|c|c|c|c|c|}
\hline \multirow[t]{2}{*}{ No. } & \multirow[t]{2}{*}{ Family } & \multirow[t]{2}{*}{ Species } & \multicolumn{5}{|c|}{ Number of individuals } \\
\hline & & & SP1 & SP2 & SP3 & SP4 & Total \\
\hline 1 & Adiantaceae & Adiantum flabellulatum $\mathrm{L}$. & 0 & 1 & 0 & 12 & 13 \\
\hline 2 & Anacardiaceae & Toxicodendron succedaneum (L.) O. Kuntze & 0 & 0 & 2 & 3 & 5 \\
\hline 3 & Annonaceae & Desmos chinensis Lour. & 0 & 0 & 2 & 0 & 2 \\
\hline 4 & Aquifoliaceae & Ilex chinensis Sims & 0 & 0 & 0 & 1 & 1 \\
\hline 5 & & Ilex pubescens Hook. et Arn. & 0 & 4 & 3 & 2 & 9 \\
\hline 6 & Araliaceae & Schefflera heptaphylla (Linnaeus) Frodin & 14 & 4 & 8 & 9 & 35 \\
\hline 7 & Blechnaceae & Blechnum orientale $\mathrm{L}$. & 0 & 6 & 0 & 3 & 9 \\
\hline 8 & & Brainea insignis (Hook.) J. Sm. & 12 & 22 & 17 & 23 & 74 \\
\hline 9 & Chloranthaceae & Sarcandra glabra (Thunb.) Nakai & 5 & 1 & 0 & 0 & 6 \\
\hline 10 & Connaraceae & Rourea microphylla (Hook. et Arn.) Planch. & 0 & 1 & 1 & 0 & 2 \\
\hline 11 & Daphniphyllaceae & Daphniphyllum calycinum Benth. & 0 & 0 & 2 & 0 & 2 \\
\hline 12 & Dilleniaceae & Tetracera sarmentosa Vahl. & 0 & 0 & 3 & 0 & 3 \\
\hline 13 & Dryopteridaceae & Cyrtomium fortunei J. Sm. & 2 & 0 & 0 & 0 & 2 \\
\hline 14 & Ebenaceae & Diospyros morrisiana Hance & 1 & 1 & 3 & 8 & 13 \\
\hline 15 & Elaeocarpaceae & Elaeocarpus japonicus Sieb. et Zucc. & 0 & 1 & 0 & 0 & 1 \\
\hline 16 & & Elaeocarpus sylvestris (Lour.) Poir. & 1 & 0 & 0 & 0 & 1 \\
\hline 17 & Ericaceae & Rhododendron moulmainense Hook. $\mathrm{f}$. & 0 & 0 & 0 & 3 & 3 \\
\hline 18 & Euphorbiaceae & Triadica cochinchinensis Loureiro & 0 & 0 & 1 & 1 & 2 \\
\hline 19 & Fabaceae & Archidendron lucidum (Benth) I. C. Nielsen & 0 & 0 & 2 & 0 & 2 \\
\hline 20 & & Dalbergia hupeana Hance & 1 & 0 & 0 & 0 & 1 \\
\hline 21 & & Dalbergia millettii Benth. & 0 & 0 & 0 & 1 & 1 \\
\hline 22 & Fagaceae & Lithocarpus glaber (Thunb.) Nakai & 109 & 55 & 166 & 123 & 453 \\
\hline 23 & Gleicheniaceae & Dicranopteris pedata (Houttuyn) Nakaike & 10 & 6 & 6 & 42 & 64 \\
\hline 24 & Guttiferae & Cratoxylum cochinchinense (Lour.) Bl. & 0 & 0 & 0 & 6 & 6 \\
\hline 25 & Iteaceae & Itea chinensis Hook. et Arn. & 3 & 0 & 1 & 0 & 4 \\
\hline 26 & Lauraceae & Cinnamomum parthenoxylon (Jack) Meisner & 0 & 0 & 1 & 0 & 1 \\
\hline 27 & & Lindera nacusua (D. Don) Merr. & 0 & 0 & 1 & 0 & 1 \\
\hline 28 & & Machilus pauhoi Kanehira & 0 & 0 & 1 & 0 & 1 \\
\hline 29 & & Machilus velutina Champ. ex Benth. & 0 & 0 & 0 & 4 & 4 \\
\hline 30 & Leguminosae & Astragalus camptodontus Franch. & 0 & 0 & 0 & 1 & 1 \\
\hline 31 & Lindsaeaceae & Lindsaea orbiculata (Lam.) Mett. ex Kuhn & 56 & 36 & 7 & 17 & 116 \\
\hline 32 & Lygodiaceae & Lygodium japonicum (Thunb.) Sw. & 1 & 0 & 0 & 5 & 6 \\
\hline 33 & & Lygodium flexuosum (L.) Sw. & 0 & 0 & 2 & 0 & 2 \\
\hline 34 & Melastomataceae & Melastoma sanguineum Sims. & 0 & 0 & 1 & 0 & 1 \\
\hline 35 & Moraceae & Ficus hirta Vahl & 0 & 1 & 1 & 0 & 2 \\
\hline 36 & & Ficus variolosa Lindl. ex Benth. & 0 & 1 & 1 & 0 & 2 \\
\hline 37 & & Litsea rotundifolia var. oblongifolia & 3 & 12 & 12 & 20 & 47 \\
\hline 38 & Myrtaceae & Syzygium hancei Merr. et Perry & 31 & 6 & 11 & 11 & 59 \\
\hline 39 & Pentaphylacaceae & $\begin{array}{l}\text { Adinandra millettii (Hook. et Arn.) Benth. et Hook. f. } \\
\text { ex Hance }\end{array}$ & 0 & 1 & 7 & 4 & 12 \\
\hline
\end{tabular}




\section{Appendix (continue)}

\begin{tabular}{|c|c|c|c|c|c|c|c|}
\hline \multirow[t]{2}{*}{ No. } & \multirow[t]{2}{*}{ Family } & \multirow[t]{2}{*}{ Species } & \multicolumn{5}{|c|}{ Number of individuals } \\
\hline & & & SP1 & SP2 & SP3 & $\mathrm{SP} 4$ & Total \\
\hline 40 & Phyllanthaceae & Aporosa dioica (Roxburgh) Muller Argoviensis & 1 & 7 & 5 & 1 & 14 \\
\hline 41 & & Glochidion wrightii Benth. & 0 & 0 & 1 & 1 & 2 \\
\hline 42 & & Glochidion zeylanicum (Gaerthn.) A. Juss. & 0 & 0 & 2 & 1 & 3 \\
\hline 43 & Poaceae & Lophatherum gracile Brongn. & 27 & 0 & 13 & 7 & 47 \\
\hline 44 & Primulaceae & Ardisia hanceana $\mathrm{Mez}$ & 1 & 4 & 3 & 3 & 11 \\
\hline 45 & & Ardisia brevicaulis Diels & 1 & 0 & 0 & 0 & 1 \\
\hline 46 & & Embelia laeta (L.) Mez & 0 & 1 & 0 & 0 & 1 \\
\hline 47 & Pteridaceae & Pteris semipinnata & 0 & 1 & 0 & 0 & 1 \\
\hline 48 & Rosaceae & Photinia serratifolia (Desfontaines) Kalkman & 4 & 0 & 0 & 0 & 4 \\
\hline 49 & & Rhaphiolepis indica (Linnaeus) Lindley & 0 & 5 & 1 & 8 & 14 \\
\hline 50 & Rubiaceae & Adina pilulifera (Lam.) Franch. ex Drake & 0 & 0 & 0 & 1 & 1 \\
\hline 51 & & Diplospora dubia (Lindl.) Masam. & 0 & 0 & 3 & 0 & 3 \\
\hline 52 & & Gardenia jasminoides Ellis & 0 & 0 & 1 & 1 & 2 \\
\hline 53 & & Mussaenda pubescens Ait. F. Hort. Kew. Ed. & 0 & 1 & 1 & 7 & 9 \\
\hline 54 & & Psychotria asiatica Wall. & 51 & 142 & 177 & 105 & 475 \\
\hline 55 & & Pavetta arenosa Lour. & 0 & 0 & 0 & 1 & 1 \\
\hline 56 & Rutaceae & $\begin{array}{l}\text { Melicope pteleifolia (Champion ex Bentham) T. G. } \\
\text { Hartley }\end{array}$ & 0 & 0 & 1 & 2 & 3 \\
\hline 57 & Santalaceae & Dendrotrophe frutescens (Blume) Miquel & 0 & 0 & 1 & 1 & 2 \\
\hline 58 & Smilacaceae & Smilax china $\mathrm{L}$ & 0 & 0 & 0 & 8 & 8 \\
\hline 59 & Theaceae & Polyspora axillaris (Roxburgh ex Ker Gawler) Sweet & 0 & 0 & 0 & 1 & 1 \\
\hline 60 & & Schima superba Gardn. et Champ. & 0 & 0 & 5 & 0 & 5 \\
\hline 61 & Thymelaeaceae & Aquilaria sinensis (Lour.) Spreng. & 1 & 2 & 0 & 3 & 6 \\
\hline 62 & & Wikstroemia nutans Champ. ex Benth. & 0 & 0 & 1 & 0 & 1 \\
\hline 63 & Zingiberaceae & Alpinia oblongifolia Hayata & 0 & 1 & 0 & 0 & 1 \\
\hline
\end{tabular}

$\mathrm{SP}=$ sample plot 